\title{
Evaluation of Oral Anti-HCV Therapy (OAT) Effects on Serum Lipids Profile in Diabetic Patients
}

\author{
Abdou Mabrouk Al-Shafey*, Diaa Mohammad Eltebi*, \\ Islam Abdel-Mawla Ammar*, Mohamad Ali Alnadar* \\ *Department of Tropical Medicine, Faculty of Medicine, Al-Azhar University, Cairo, Egypt. \\ Corresponding author: Mohamad Ali Alnadar, E-mail: Mohamedali1990529@gmail.com
}

\begin{abstract}
:
Background: hepatitis C Virus (HCV) has complex interactions with human lipid metabolism leading to down regulation of cholesterol level. Interferon (INF) therapy has been shown to decrease cholesterol even further during treatment .With the availability of direct acting antiviral agents (DAAs) the effect of suppressing HCV on lipid metabolism warrantes re-evaluation. Aim of the work : goal of our study was evaluation the changes in lipid profile after treatment of chronic HCV infection with oral antiviral medications in diabetic patients. Methods: this prospective study conducted on $90 \mathrm{HCV}$ infected patients, all patients received Sofosbuvir (SOF) \& Daclatasvir (DCV) as a dual therapy for 3 months. They were divided according to the presence or absence of diabetes mellitus (DM) and hyperlipidemia into three main groups; Group I: included 30 diabetic hyperlipidemic patients, Group II: included 30 non-diabetic hyperlipidemic patients, Group III: included 30 non-diabetic nondyslipidemia patients.Changes of lipid profile on treatment with DAAs were assessed by checking fasting lipid profile at base line, then at end of treatment, and finally 3 months after treatment. Results: there was a statistically significant increase in total cholesterol level (TCHOL) which was maintained after the end of therapy. Changes in TCHOL were driven by changes in low-density lipo-protein (LDL) cholesterol, whereas high-density lipo-protien (HDL) cholesterol and very low-density lipo-protein (VLDL) cholesterol showed no significant changes. There were also no significant changes in tryglyceride (TG) level on treatment. Conclusion: eliminating HCV with DAAs increased TCHOL but had no effect on TG level.
\end{abstract}

Keywords: Hepatitis C Virus, Direct- acting antivirals

\section{Introduction:}

$\mathrm{HCV}$ infection is a major cause of chronic liver disease worldwide, ultimately leading to cirrhosis and hepatocellular carcinoma (HCC), Approximately, 130-150 million people are infected with $\mathrm{HCV}$ each year, besides an estimated 399000 people die from complications of $\mathrm{HCV}$ including cirrhosis, malignant neoplastic disease (HCC) and liver failure $^{(1)}$.

Unluckily, many people with HCV only know about their infection when they experience symptoms of cirrhosis or liver cancer ${ }^{(\mathbf{1})}$.

Chronic HCV infection is associated with hepatic steatosis and hypocholesterolemia ${ }^{(2)}$, HCV utilizes peripheral lipid metabolism pathways for viral assembly and requires several apo- lipoproteins for production of infective particles ${ }^{(3)(4)}$, so patients with $\mathrm{HCV}$ infection show a reduction of serum TCHOL and LDL and Apo-lipoprotein B (Apo-B) levels (5).

The field of HCV therapeutics has evolved rapidly; in 2013, the treatment of HCV was transformed by the introduction of a new class of medicines called direct-acting antivirals (DAAs). An 8-12-week course of these medicines can cure more than $90 \%$ of persons with chronic HCV infection, These new oral treatments offer tremendous opportunities and hope to all those who are infected ${ }^{(6)}$.

Successful clearance of HCV viremia with immunomodulatory therapy (Peg INF and ribavirin) has been associated with a decrease in TCHOL and LDL ${ }^{(7)}$, But the impact of DAAs on lipid metabolism is thus far uncharacterized, so it's evaluated in our study. AIM OF THE WORK:

The aim of the current study was to evaluate the changes in lipid profile after treatment of chronic HCV infection with oral antiviral medications in diabetic patients.

\section{Patients and Methods:}

This prospective study was conducted at AlAzhar University Specialized hospital where 90 $\mathrm{HCV}$ patients related chronic liver disease 
(CLD) were selectd, All patients received SOF \& DCV as a dual therapy for 3 months at HCV treatment clinic in the period from December 2017 to March 2018. All patients signed an informed written consent after explanation of the aim of the study and the study details.

They were divided according to the presence or absence of DM and hyperlipidemia into three main groups:

Group I: included 30 diabetic hyperlipidemic patients with chronic $\mathrm{HCV}$ infection.

Group II: included 30 non-diabetic hyperlipidemic patients with chronic $\mathrm{HCV}$ infection.

Group III: This included 30 non-diabetic nondyslipidemia patients with chronic $\mathrm{HCV}$ infection.

Application of inclusion and exclusion criteria was taking in consideration the Egyptian National HCV Control Program guide lines ${ }^{(\mathbf{8})}$ :

Inclusion criteria included the following: the age range was between 18 and 75 years and all patients tested positive for serum real time HCV RNA PCR.

Exclusion criteria included the following: patients who are co-infected with Human Imuno-deficiency Virus(HIV) or Hepatitis B Virus (HBV), patients who $<18$ or $>75$ years old, Pregnant female, patients who has HCC or other extrahepatic malignancy, Whose Total serum total bilirubin more than $3 \mathrm{mg} / \mathrm{dl}$, Serum albumin less than $2.8 \mathrm{~g} / \mathrm{dl}$,International normalized ratio (INR) more than 1.7, Platelet count less than 50,000/mm, Renal impairment with estimated glomerular filtration rate (e GFR) less than $30 \mathrm{ml} /$ minute, Non-compliant patients ,Whose hemoglobin $(\mathrm{Hb})$ level less than $10 \mathrm{~g} / \mathrm{dl}$ and $\mathrm{HbA} 1 \mathrm{C}>9 \%$.

All patients were subjected to detailed history taking including age, sex, history of other comorbid conditions such as diabetes, hypertension, Cardiac disease and renal failure, history of drugs including anti diabetic, antihypertensive or antihyperlipidemic drugs, history of previous treatment with anti-HCV medicines (e.g. peg INF plus ribavirin, SOF plus Ribavirin or other combination regimens) Results: were also evaluated and measurement of body mass index (BMI).

Before starting DAAs therapy, laboratory tests were carried out that included, twelve hours fasting plasma lipid profile included serum TCHOL, LDL, HDL, VLDL and T.G level \}, eight hours fasting blood glucose (FBG), Two hours post prandial blood glucose (2HPPBG), glycosylated hemoglobin (HbA1c), qualitative HCV RNA serum PCR test, liver enzymes, serum bilirubin, serum albumin, and INR, serum creatinine, and complete blood picture (CBC).

Changes of lipid profile on treatment with DAAS were assessed by checking fasting lipid profile at base line, then at the end of treatment (i.e $12^{\text {th }}$ week of treatment), and finally 3 months after treatment (i.e $24^{\text {th }}$ week of treatment).

Treatment was considered successful when patients became non-viremic as identified by negative HCV RNA serum PCR at 12 weeks from the end of the treatment regimens; this is called SVR.

The study was done according to the ethical board of Al-Azhar University .

Statistical analysis:

Data were analyzed using Statistical Program for Social Science (SPSS) version 15.0.

Quantitative data were expressed as mean \pm standard deviation (SD). Qualitative data were expressed as frequency and percentage.

The following tests were done:

Chi-square test: was used when comparing between non-parametric data.

A one-way analysis of variance (ANOVA): when comparing between more than two means.

Post Hoc test: was used for multiple comparisons between different variables.

Probability (P-value)

- P-value <0.05 was considered significant.

- P-value <0.001 was considered as highly significant.

- P-value >0.05 was considered insignificant. 
Table (1): Comparison between studied lipid profiles (at base, 12 wk and 24 wk) in group I (Diabetic Dyslipidemic):

\begin{tabular}{|c|c|c|c|c|c|}
\hline \multicolumn{2}{|c|}{ Time point } & $\begin{array}{l}\text { At base } \\
(\mathbf{N}=30)\end{array}$ & $\begin{array}{l}12 \text { wk } \\
(N=30)\end{array}$ & $\begin{array}{l}24 \text { wk } \\
(N=30)\end{array}$ & $\begin{array}{l}\text { ANOVA } \\
\text { p-value }\end{array}$ \\
\hline \multirow{2}{*}{$\begin{array}{l}\text { TCHOL } \\
\text { (mg/dl) }\end{array}$} & Mean & 228.1 & 243.4 & 247 & \multirow{2}{*}{$<0.001 *$} \\
\hline & \pm SD & 12.1 & 8.5 & 9.8 & \\
\hline \multirow{2}{*}{$\begin{array}{l}\text { LDL } \\
\text { (mg/dl) }\end{array}$} & Mean & 158.2 & 175.3 & 177.3 & \multirow{2}{*}{$<0.001 *$} \\
\hline & \pm SD & 8.3 & 8.4 & 8.1 & \\
\hline \multirow{2}{*}{$\begin{array}{l}\text { HDL } \\
\text { (mg/dl) }\end{array}$} & Mean & 36.1 & 37.1 & 36.7 & \multirow{2}{*}{0.3} \\
\hline & \pm SD & 3.1 & 2.3 & 2.6 & \\
\hline \multirow{2}{*}{$\begin{array}{l}\text { T.G } \\
\text { (mg/dl) }\end{array}$} & Mean & 178 & 178.5 & 180.5 & \multirow{2}{*}{0.5} \\
\hline & \pm SD & 9.02 & 8.9 & 7.04 & \\
\hline \multirow{2}{*}{$\begin{array}{l}\text { VLDL } \\
(\mathrm{mg} / \mathrm{dl})\end{array}$} & Mean & 35 & 35.5 & 36.1 & \multirow{2}{*}{0.2} \\
\hline & \pm SD & 2.1 & 2.8 & 2.04 & \\
\hline
\end{tabular}

This table (1) shows highly statistical significant difference (p-value $<\mathbf{0 . 0 0 1}$ ) in TCHOL and LDL level (at base, $12 \mathrm{wk}$ and $24 \mathrm{wk}$ ) where as there is no statistical significant difference (p-value $>\mathbf{0 . 0 5}$ ) in HDL, T.G and VLDL levels (at base, $12 \mathrm{wk}$ and $24 \mathrm{wk}$ ) in group I.

Table (2): Comparison between studied lipid profiles (at base, 12 wk and 24 wk) as in group II (Non Diabetic Dyslipidemic)

\begin{tabular}{|c|c|c|c|c|c|}
\hline \multicolumn{2}{|c|}{$\begin{array}{l}\text { Time point } \\
\text { Variables }\end{array}$} & $\begin{array}{l}\text { At base } \\
(\mathbf{N}=\mathbf{3 0})\end{array}$ & $\begin{array}{l}12 \text { wk } \\
(N=30)\end{array}$ & $\begin{array}{l}24 \text { wk } \\
(N=30)\end{array}$ & $\begin{array}{l}\text { ANOVA } \\
\text { p-value }\end{array}$ \\
\hline \multirow{2}{*}{$\begin{array}{l}\text { TCHOL } \\
\text { (mg/dl) }\end{array}$} & Mean & 211.1 & 226.7 & 231 & \multirow{2}{*}{$<0.001 *$} \\
\hline & \pm SD & 6.6 & 5.7 & 6.1 & \\
\hline \multirow{2}{*}{$\begin{array}{l}\text { LDL } \\
\text { (mg/dl) }\end{array}$} & Mean & 138.2 & 155.2 & 157.4 & \multirow{2}{*}{$<0.001 *$} \\
\hline & \pm SD & 4.03 & 8.02 & 8.4 & \\
\hline \multirow{2}{*}{$\begin{array}{l}\text { HDL } \\
(\mathrm{mg} / \mathrm{dl})\end{array}$} & Mean & 37.5 & 39 & 38.5 & \multirow{2}{*}{0.05} \\
\hline & \pm SD & 2.1 & 2.5 & 2.4 & \\
\hline \multirow{2}{*}{$\begin{array}{l}\text { T.G } \\
\text { (mg/dl) }\end{array}$} & Mean & 170 & 171 & 172.5 & \multirow{2}{*}{0.4} \\
\hline & $\pm \mathrm{SD}$ & 7.3 & 7.5 & 6.4 & \\
\hline \multirow{2}{*}{$\begin{array}{l}\text { VLDL } \\
\text { (mg/dl) }\end{array}$} & Mean & 34 & 34.2 & 34.5 & \multirow{2}{*}{0.7} \\
\hline & \pm SD & 2.3 & 2.5 & 2.8 & \\
\hline
\end{tabular}

Table (2) shows highly statistical significant difference (p-value $<\mathbf{0 . 0 0 1}$ ) in TCHOL and LDL levels (at base, $12 \mathrm{wk}$ and $24 \mathrm{wk}$ ) where as thrre is no statistical significant difference (p-value $>\mathbf{0 . 0 5}$ ) in HDL, T.G and VLDL levels (at base, $12 \mathrm{wk}$ and $24 \mathrm{wk}$ ) in group II.

Table (3 ): Comparison between studied lipid profiles (at base, 12 wk and 24 wk) as in group III (Non Diabetic non Dyslipidemic).

\begin{tabular}{|c|c|c|c|c|c|}
\hline \multicolumn{2}{|c|}{$\begin{array}{l}\text { Time point } \\
\text { Variables }\end{array}$} & $\begin{array}{l}\text { At base } \\
(\mathbf{N}=30)\end{array}$ & $\begin{array}{l}12 \text { wk } \\
(N=30)\end{array}$ & $\begin{array}{l}24 \text { wk } \\
(N=30)\end{array}$ & $\begin{array}{l}\text { ANOVA } \\
\text { p-value }\end{array}$ \\
\hline \multirow{2}{*}{$\begin{array}{l}\text { TCHOL } \\
(\mathrm{mg} / \mathrm{dl})\end{array}$} & Mean & 165 & 181.2 & 186.1 & \multirow{2}{*}{$<0.001 *$} \\
\hline & \pm SD & 10.6 & 6.9 & 6.1 & \\
\hline \multirow{2}{*}{$\begin{array}{l}\text { LDL } \\
(\mathrm{mg} / \mathrm{dl})\end{array}$} & Mean & 89 & 107.5 & 109.2 & \multirow{2}{*}{$<0.001 *$} \\
\hline & \pm SD & 5.1 & 17.01 & 7.5 & \\
\hline \multirow{2}{*}{$\begin{array}{l}\text { HDL } \\
(\mathrm{mg} / \mathrm{dl})\end{array}$} & Mean & 56.4 & 57.5 & 57 & \multirow{2}{*}{0.09} \\
\hline & \pm SD & 2.04 & 1.9 & 1.7 & \\
\hline \multirow{2}{*}{$\begin{array}{l}\text { T.G } \\
(\mathrm{mg} / \mathrm{dl})\end{array}$} & Mean & 90 & 91 & 92 & \multirow{2}{*}{0.2} \\
\hline & \pm SD & 3.7 & 4.1 & 4.1 & \\
\hline \multirow{2}{*}{$\begin{array}{l}\text { VLDL } \\
\text { (mg/dl) }\end{array}$} & Mean & 17.5 & 18 & 18.4 & \multirow{2}{*}{0.3} \\
\hline & \pm SD & 2.4 & 2.1 & 2.4 & \\
\hline
\end{tabular}


Table (3) shows highly statistical significant difference (p-value $<\mathbf{0 . 0 0 1}$ ) in TCHOL and LDL levels (at base, $12 \mathrm{wk}$ and $24 \mathrm{wk}$ ) where as there is no statistical significant difference (p-value $>\mathbf{0 . 0 5}$ ) between HDL, T.G and VLDL levels (at base, $12 \mathrm{wk}$ and $24 \mathrm{wk}$ ) in group III.

Table (4): Comparison between studied groups as regard the percentage of increase in lipid profile items at 0:24 weeks:

\begin{tabular}{|c|c|c|c|c|c|}
\hline \multicolumn{2}{|c|}{$\begin{array}{l}\text { Groups } \\
\text { At 0:24 weeks }\end{array}$} & $\begin{array}{l}\text { Group I } \\
(\mathbf{N}=\mathbf{3 0})\end{array}$ & $\begin{array}{l}\text { Group II } \\
(\mathbf{N}=\mathbf{3 0})\end{array}$ & $\begin{array}{l}\text { Group III } \\
(\mathbf{N}=\mathbf{3 0})\end{array}$ & $\begin{array}{l}\text { ANOVA } \\
\text { p-value }\end{array}$ \\
\hline \multirow{2}{*}{$\begin{array}{l}\text { TCHOL } \\
\text { (\%) }\end{array}$} & Mean & 8.56 & 9.52 & 10.1 & \multirow{2}{*}{0.09} \\
\hline & \pm SD & 7.21 & 4.37 & 7.70 & \\
\hline \multirow{2}{*}{$\begin{array}{l}\text { LDL } \\
(\%)\end{array}$} & Mean & 12.35 & 14.02 & 11.9 & \multirow{2}{*}{0.4} \\
\hline & \pm SD & 8.14 & 6.66 & 9.58 & \\
\hline \multirow{2}{*}{$\begin{array}{l}\text { HDL } \\
(\%)\end{array}$} & Mean & 2.44 & 2.80 & 1.20 & \multirow{2}{*}{0.7} \\
\hline & $\pm \mathrm{SD}$ & 10.17 & 6.21 & 5.11 & \\
\hline \multirow{2}{*}{$\begin{array}{l}\text { T.G } \\
(\%)\end{array}$} & Mean & 1.51 & 1.58 & 2.25 & \multirow{2}{*}{0.8} \\
\hline & \pm SD & 3.91 & 4.75 & 4.12 & \\
\hline \multirow{2}{*}{$\begin{array}{l}\text { VLDL } \\
(\%)\end{array}$} & Mean & 3.50 & 1.53 & 6.15 & \multirow{2}{*}{0.2} \\
\hline & \pm SD & 8.45 & 5.69 & 13.66 & \\
\hline
\end{tabular}

- Table (4) shows no statistical significant difference (p-value $>\mathbf{0 . 0 5}$ ) between studied groups as regard the percentage of increase in TCHOL, LDL, HDL, TG and VLDL at 0:24 weeks..

Table (5): Correlation study between the percentage of increase in TCHOL (At 0:24 weeks) and (age, BMI \& base line CHOL) in group I:

\begin{tabular}{|l|l|l||}
\hline Group I & (r) & p-value \\
\hline \hline \% of increased TCHOL vs age & -0.3 & 0.1 \\
\hline \hline \% of increased TCHOL vs BMI & 0.09 & 0.6 \\
\hline \hline \% of increased TCHOL vs baseline CHOL & -0.8 & $<\mathbf{0 . 0 0 1 * *}$ \\
\hline
\end{tabular}

Table (5) shows highly statistical significant (p-value $<\mathbf{0 . 0 0 1})$ Negative correlation $(\mathbf{r}=\mathbf{- 0 . 5})$ between the percentage of increase in TCHOL (At 0:24 weeks) and base line TCHOL where as there is no statistical significant ( $\mathbf{p}$-value $>\mathbf{0 . 0 5}$ ) correlation between the percentage of increase in TCHOL (At $0: 24$ weeks) and (age \& BMI) in group I.

Table (6 ): Correlation study between \% of increased TCHOL (0:24) and (age, BMI \& base line TCHOL) in groupII:

\begin{tabular}{|l||l|l|}
\hline Group II & (r) & p-value \\
\hline \hline \% of increased TCHOL vs age & 0.4 & 0.9 \\
\hline \hline \% of increased TCHOL vs BMI & 0.2 & 0.4 \\
\hline \% of increased TCHOL vs baseline CHOL & -0.7 & $<\mathbf{0 . 0 0 1 * *}$ \\
\hline
\end{tabular}

Table (6) shows highly statistical significant (p-value $<\mathbf{0 . 0 0 1}$ ) Negative correlation $(\mathbf{r}=\mathbf{- \mathbf { 0 . 7 }})$ between the percentage of increase in TCHOL (At 0:24 weeks) and base line TCHOL where as there is no statistical significant (p-value $>\mathbf{0 . 0 5}$ ) correlation between \% of increased TCHOL (At 0:24 weeks) and (age \& BMI) in group II.

Table (7 ): Correlation study between \% of increased TCHOL (0:24) and (age, BMI \& base line TCHOL) in group III

\begin{tabular}{|l|l|l|}
\hline Group III & $(\mathbf{r})$ & p-value \\
\hline \% of increased TCHOL vs age & 0.3 & 0.1 \\
\hline \hline$\%$ of increased TCHOL vs BMI & 0.07 & 0.7 \\
\hline \% of increased TCHOL vs baseline TCHOL & -0.9 & $<\mathbf{0 . 0 0 1 *}$ \\
\hline
\end{tabular}


Table (7) shows highly statistical significant (pvalue $<\mathbf{0 . 0 0 1})$ Negative correlation $(\mathbf{r}=\mathbf{- 0 . 9})$ between the percentage of increase in TCHOL (At 0:24 weeks) and base line TCHOL where as there is no statistical significant (p-value > 0.05) correlation between the percentage of increase in TCHOL (At 0:24 weeks) and (age \& BMI) in group III.

\section{Discussion:}

$\mathrm{HCV}$ infection is a major cause of chronic liver disease worldwide, ultimately leading to cirrhosis and $\mathrm{HCC}^{(\mathbf{8})}$.

Chronic HCV infection is associated with hepatic steatosis and hypocholesterolemia ${ }^{(2)}$, $\mathrm{HCV}$ utilizes peripheral lipid metabolism pathways for viral assembly and requires several apo-lipo-proteins for production of infective particles (3), so patients with $\mathrm{HCV}$ infection show a reduction of serum TCHOL, LDL and Apo-B levels ${ }^{(5)}$.

Successful clearance of $\mathrm{HCV}$ viremia with immunomodulatory therapy (Peg INF and ribavirin) has been associated with a rise in TCHOL, and LDL ${ }^{(6)}$. But the impact of DAAs on lipid metabolism is thus far uncharacterized so it's evaluated in our study.

In this study we found that there was an increase in TCHOL from baseline to 24 week of treatment in the studied groups, and this increase was highly statistical significant (pvalue < 0.001); In group I: TCHOL was $(228.1 \pm 12.1 \mathrm{mg} / \mathrm{dl})$ at baseline, then $(243.4 \pm$ $8.5 \mathrm{mg} / \mathrm{dl})$ at 12 weeks, and $(247 \pm 9.8 \mathrm{mg} / \mathrm{dl})$ at 24 weeks, In group II: TCHOL was $(211.1$ $\pm 6.6 \mathrm{mg} / \mathrm{dl})$ at baseline, then $(226.7 \pm 5.7$ $\mathrm{mg} / \mathrm{dl})$ at 12 weeks, and $(231 \pm 6.1 \mathrm{mg} / \mathrm{dl})$ at 24 weeks, In group III: TCHOL was $(165 \pm 10.6$ $\mathrm{mg} / \mathrm{dl})$ at baseline, then $(181.2 \pm 6.9 \mathrm{mg} / \mathrm{dl})$ at 12 weeks, and $(186.1 \pm 6.1 \mathrm{mg} / \mathrm{dl})$ at 24 weeks. There were no significant statistical differences between the studied groups as regard the rise in TCHOL (p-value > 0.05); In group I: the percentage of increase in TCHOL from baseline to week 12 was $(7.01 \pm 6.73, \mathrm{mg} / \mathrm{dl})$, and from baseline to week 24 was $(8.56 \pm 7.21 \mathrm{mg} / \mathrm{dl})$, In group II: the percentage of increase in TCHOL from baseline to week 12 was $(7.50 \pm 4.13$ $\mathrm{mg} / \mathrm{dl})$, and from baseline to week 24 was $(9.52$ $\pm 4.37, \mathrm{mg} / \mathrm{dl})$, In group III: the percentage of increase in TCHOL from baseline to week 12 was $(10.16 \pm 6.76, \mathrm{mg} / \mathrm{dl})$, and from baseline to week 24 was $(10.1 \pm 7.70 \mathrm{mg} / \mathrm{dl})$.

This increase in total cholesterol was driven by mainly increase in LDL, as we found that there was an increase in LDL in the studied groups and this increase was highly statistically significant (p-value < 0.001); In group I: LDL was $(158.2 \pm 8.3 \mathrm{mg} / \mathrm{dl})$ at baseline, then $(175.3$ $\pm 8.4 \mathrm{mg} / \mathrm{dl})$ at 12 weeks, and $(177.3 \pm 8.1$ $\mathrm{mg} / \mathrm{dl})$ at 24 weeks, In group II: LDL was $(138.2 \pm 4.03, \mathrm{mg} / \mathrm{dl})$ at baseline, then $(155.2 \pm$ $8.02, \mathrm{mg} / \mathrm{dl})$ at 12 weeks, and $(157.4 \pm 8.4$, $\mathrm{mg} / \mathrm{dl})$ at 24 weeks, In group III: LDL was (89 $\pm 5.1, \mathrm{mg} / \mathrm{dl})$ at baseline, then $(107.5 \pm 17.01$, $\mathrm{mg} / \mathrm{dl})$ at 12 weeks, and $(109.2 \pm 7.5, \mathrm{mg} / \mathrm{dl})$ at 24 weeks.

There was no significant statistical difference, between the studied groups as regard the rise in LDL (p-value > 0.05); In group I: the percentage of increase in LDL from baseline to week 12 was $(11.11 \pm 8.49, \mathrm{mg} / \mathrm{dl})$, and from baseline to week 24 was $(12.35 \pm 8.14, \mathrm{mg} / \mathrm{dl})$, In group II: the percentage of increase in LDL from baseline to week 12 was $(12.38 \pm 5.78$, $\mathrm{mg} / \mathrm{dl}$ ), and from baseline to week 24 was $(14.02 \pm 6.66, \mathrm{mg} / \mathrm{dl})$, In group III: the percentage of increase in LDL from baseline to week 12 was $(11.8 \pm 6.86, \mathrm{mg} / \mathrm{dl})$, and from baseline to week 24 was $(11.9 \pm 9.58, \mathrm{mg} / \mathrm{dl})$.

As regard HDL, VLDL and T.G, There was no significant statistical difference in any group neither in at $12^{\text {th }}$ week, nor $24^{\text {th }}$ weeks of the study as compared with base line levels (pvalue $>0.05$ ).

Our findings of increase in TCHOL, and LDL, after eradication of $\mathrm{HCV}$ can be explained by a return to 'normal' pre-infection lipid patterns after elimination of the effect of HCV on lipid levels.

Our results were in agreement with Mauss et al.(10) who found that there was a rapid significant increase of TCHOL (by amedian +17 'IQR: 6-32' at end of treatment and by median +22 'IQR: $1-43^{\prime}$ at 12 weak after end of treatment) and LDL-cholesterol (by amedian +13 'IQR:3-24' at end of treatment and by median +17 'IQR:-2-39' at 12 weak after end of treatment) as compared with baseline values $(\mathrm{P}<0.001$, respectively) in a larger number of patients treated with a variety of DAA combinations while HDL-cholesterol and TG levels remain unchanged during and after therapy ${ }^{(10)}$.

Our results were also in agreement with Gitto $\mathrm{S}$, et al ${ }^{\left({ }^{11}\right)}$.who found that HDL and TG levels did not change over time of treatment with various DAA combinations, but the mean TCHOL and LDL values were significantly increased (from $154 \pm 34$ to $170 \pm 37 \mathrm{mg} / \mathrm{dL}$, p 
$<0.001$ and from $80 \pm 26$ to $102 \pm 34 \mathrm{mg} / \mathrm{dL}, \mathrm{p}$ $<0.001$, respectively) ${ }^{(11)}$.

In this study, there was a highly statistical significant (p-value $<0.001$ ) negative correlation between the percent of increased TCHOL (0:24) and base line TCHOL in the studied groups, but there was no statistical significant ( $\mathrm{p}$-value $>0.05)$ correlation between $\%$ of increased TCHOL $(0: 24)$ and other variables (e.g. age, sex, BMI \& presence or absence of DM) in the studied groups and this was in agreement with Mauss et al. ${ }^{(\mathbf{1 0})}$ who found that there were no risk factors for increase TCHOL except lower baseline TCHOL ${ }^{(10)}$.

Conclusion:

This study concluded that there is significant increase in TCHOL mainly driven by increase in LDL cholesterol after successful clearance of HCV by DAAs regardless presence or absence of Diabetes.

\section{References:}

1. WHO (2017): Hepatitis C. Available at: www.who.int/mediacentre/factsheets/fs 164/en/ $>$

2. Chang ML (2016) :Metabolic alterations and hepatitis C:From bench to bedside. World J Gastroenterol.,28:22(4):146-76.

3. Del c and Romero G (2015): Modulation of host lipid metabolism by hepatitis $\mathrm{C}$ virus:Role of new therapies .World $\mathrm{J}$ Gastroenterol.,21(38):10776-82.

4. Hezode C, Roudot-Thoraval F, Zafrani ES et al.(2004):Different mechanisms of teatosis in hepatitis $\mathrm{C}$ virus genotypes 1 and 3 infections. J Viral Hepat..,: 11(5):455-8.

5. Bugianesi E, Salamone F, Negro F et al., (2012): The interaction of metabolic factors with HCV infection: does it matter? J Hepatol 2012; 56: S56-S65.

6. WHO (2016): Global report on access to hepatitis $\mathrm{C}$ treatment. Focus on overcoming barriers Available at:www.who.int/hepatitis/publications/hep-caccess-report/en/.

7. Corey KE, Kane E, Munroe C et al. (2009) :Hepatitis $C$ virus infection and its clearance alter circulating lipids: implications for long-term follow-up . Hepatology,50 (4):1030-7.

8.El-Akel W, El-Sayed MH, El Kassas M et al. (2017): National treatment programme of hepatitis C in Egypt: Hepatitis C virus model of care. J Viral Hepat .,24(4):262-267.

9. Mohd Hanafiah K, Groeger J, Flaxman AD et al. (2013): Global epidemiology of hepatitis $\mathrm{C}$ virus infection: new estimates of age-specific antibody to $\mathrm{HCV}$ seroprevalence. Hepatology, 57:133342.

10. Mauss S, Berger F, Wehmeyer MH et al. (2017): Effect of antiviral therapy for HCV on lipid levels.Antivir Ther .,21(1):81-88.

11. Gitto S, Arrigo F, Elisabetta L et al. (2017): Worsening of Serum Lipid Profile after Direct Acting Antiviral Treatment, Annals of hepatology , 17 (1): 64-75. 